\title{
KUALITAS PELAYANAN PUBLIK DI KANTOR DINAS KEPENDUDUKAN DAN CATATAN SIPIL KABUPATEN GORONTALO
}

\author{
Juriko Abdussamad \\ Universitas Negeri Gorontalo \\ jurikoabdussamad@yahoo.co.id
}

\begin{abstract}
ABSTRAK
Penelitin ini bertujuan untuk mengetahui gambaran secara deskriptif mengenai Pelayanan Publik dan Kualitas Pelayanan Publik di Kantor Dinas Kependudukan dan Catatan Sipil Kabupaten Gorontalo. Penelitian menunjukkan bahwa Kualitas Pelayanan Publik di Kantor Dinas Kependudukan dan Catatan Sipil Kabupaten Gorontalo masih belum baik, hal ini dapat dilihat melalui beberapa hal, seperti halnya upaya peningkatan profesionalisme aparatur yang masih kurang, melaksanakan pelayanan yang belum tepat waktu. Temuan dari penelitian menunjukkan ada dalam beberapa hal yang menyebabkan pelayanan yang masih kurang baik dari sisi profesionalisme aparatur dan ketepatan waktu dalam kerja. Kesemua hal ini perlu untuk diperbaiki dengan memperhatikan sisi kualifikasi aparatur dalam memberikan pelayanan. Baik dalam hal Reliability (Kehandalan), Responsivenees (Daya tanggap), dan Assurance (Jaminan). Faktor-faktor pendukung seperti Motivasi kerja dan Kerja sama. Faktor-faktor penghambat seperti Sumber Daya Manusia (SDM), Sarana dan Prasarana.
\end{abstract}

\section{Kata Kunci: Pelayanan Publik, Kualitas, Public Services, Quality}

\section{PENDAHULUAN}

Pelayanan publik merupakan salah satu tugas penting yang tidak dapat diabaikan oleh pemerintah daerah sebab jika komponen pelayanan terjadi stagnasi (kemacetan) maka hampir dipastikan semua sektor akan berdampak kemacetan, oleh sebab itu perlu ada perencanaan yang baik dan bahkan perlu diformulasikan standar pelayanan masyarakat sesuai dengan kewenangan yang diberikan oleh pemerintah pusat pada pemerintah daerah. Lembaga atau organisasi pemerintah semakin dituntut untuk menciptakan kualitas pelayanan yang dapat mendorong dan meningkatkan kegiatan ekonomi masyarakat. Karena itu, pelayanan (aparatur) pemerintah harus lebih proaktif dan cermat dalam mengantisipasi paradigma baru global agar pelayanannya mampu memenuhi kebutuhan masyarakat yang dinamis.

$$
\text { Pemerintah Kabupaten }
$$
Gorontalo yang merupakan bagian dari organisasi pemerintahan 
Republik Indonesia mempunyai struktur pemerintahan Negara dari tingkat paling tinggi yakni presiden tingkat paling rendah yakni rukun Warga dan rukun Tetangga. Dinas Kependudukan dan Catatan Sipil Kabupaten Gorontalo merupakan salah satu pelaksana pelayanan administrasi publik di wilayah Kabupaten Gorontalo. Pelayanan kependudukan ini meliputi pendaftaran penduduk dan pencatatan sipil. Pendaftaran penduduk meliputi pembuatan Kartu Keluarga (KK), Kartu Tanda Penduduk Elektronik (e-KTP), surat pindah dll, sedangkan pencatatan sipil meliputi pembuatan kutipan akta kelahiran, kutipan akta kematian, kutipan akta perceraian, pencatatan pengakuan anak dan pengesahan anak, pencatatan perubahan nama, dan pencatatan perubahan kewarganegaraan.

Keberadaan pedoman umum untuk menyusun indeks kepuasan masyarakat adalah bagian dari upaya untuk menciptakan objektifitas pelayanan yang diberikan kepada masyarakat, terutama dalam rangka otonomi daerah. Kurniawan $(2005 ; 6)$ mengatakan pelayanan publik adalah pemberi pelayanan (melayani) keperluan orang lain atau masyarakat yang mempunyai kepentingan pada organisasi itu sesuai dengan aturan pokok dan tata cara yang telah ditetapkan. Pemerintah Kabupaten Gorontalo harusnya memberikan pelayanan yang baik pada masyarakat, namun pada kenyataannya, diperoleh fakta bahwa kualitas pelayanan di Dinas Kependudukan dan Catatan Sipil Kabupaten Gorontalo masih perlu ditingkatkan lagi, belum maksimalnya kualitas pelayanan yang diberikan.

Kantor Dinas Kependudukan dan Catatan Sipil Kabupaten Gorontalo masih belum maksimal terlihat dari beberapa permasalahan di dalamnya yaitu: Para pegawai masih jauh dari kata professional atau kurang memiliki ketelitian dalam memberikan pelayanan pada masyarakat, sehingga dalam proses pelaksanaan kinerja yang kurang baik sangat mempengaruhi produk pelayanan yang dilakukan oleh pegawai terhadap masyarakat contoh dalam pembuatan e-KTP masih ada kesalahan dalam penulisan nama, tanggal lahir dan tahun lahir.

\section{METODE PENELITIAN}

Metode yang digunakan adalah menggunakan pendekatan kualitatif. Menurut Moleong (2009;6) "penelitian kualitatif adalah penelitian yang bermaksud untuk memahami fenomena tentang apa yang dialami oleh subjek penelitian secara holistik dan dengan cara deskripsi dalam bentuk kata kata dan bahasa, pada suatu konteks khusus yang alamiah dan dengan memanfaatkan berbagai metode ilmiah". Penelitian kualitatif 
menggunakan analisis dan secara induktif.

Di samping itu, peneliti menggunakan jenis penelitian deskriptif dimaksudkan untuk memberikan data yang seteliti mungkin tentang suatu keadaan atau gejala gejala lainnya. Sebagaimana menurut Nawawi (Sugiono, 2009:43), bahwa metode deskriptif yaitu metode penelitian yang merumuskan perhatian pada masalah-masalah atau fenomena yang ada pada saat penelitian dilakukan atau masalah yang bersifat aktual, kemudian menggambarkan fakta-fakta tentang masalah yang diselidiki sebagaimana adanya diiringi dengan interpretasi yang rasional dan akurat dan untuk memberi gambaran yang sejelasjelasnya tentang kualitas pelayanan publik di Kantor Dinas Kependudukan dan Catatan Sipil Kabupaten Gorontalo.

Variabel terkait fokus penelitian ini, yaitu kualitas pelayanan publik Di Kantor Dinas Kependudukan dan Catatan Sipil Kabupaten Gorontalo: (1) Reliability (Kehandalan), yaitu kemampuan memberikan pelayanan yang dijanjikan dengan segera, akurat dan memuaskan. Pelayanan yang handal merupakan harapan pelanggan. Hal ini berarti pelayanan tersebut tepat waktu di setiap saat, dalam aturan yang sama dan tanpa kesalahan, Reliability (Kehandalan) memiliki indikator sebagai berikut:
Kecermatan pegawai dalam melayani pengguna layanan, Memiliki standar pelayanan yang jelas, Kemampuan menggunakan alat bantu pelayanan, Keahlian petugas menggunakan alat bantu pelayanan. (2) Responsivenes (Daya Tanggap), yaitu keinginan para staf untuk membantu para pelanggan dan memberikan pelayanan dengan tanggap. Responsivenes (Daya Tanggap) memiliki indikator sebagai berikut: Merespon setiap pelanggan, dan Pelayanan dengan cepat dan tepat. (3) Assurance (Jaminan) di antaranya petugas memberikan jaminan tepat waktu dalam pelayanan Assurance (Jaminan) memiliki indikator sebagai berikut: Jaminan tepat waktu pelayanan, dan Jaminan kepastian dalam biaya pelayanan (Hardiyansyah, 2011:53).

\section{Teknik Pengumpulan Data Observasi}

Observasi atau pengamatan merupakan alat pelengkap didalam penghimpunan data penelitian. Menurut Nisbet dan Watt (Sugiyono, 2009:115) di dalam melakukan pengamatan harus menggunakan catatan tak berstruktur dalam tahap pertama yang terbuka, dalam tahap kedua memberikan perhatian pada sejumlah kategori terpilih.

\section{Wawancara}

Wawancara adalah suatu teknik pengumpulan informasi dengan tekhnik bertanya yang bebas, tetapi berdasarkan suatu pedoman 
(sesuai dengan ruang lingkup penelitian) guna mendapatkan informasi yang dibutuhkan.

Wawancara ini mempergunakan pedoman wawancara berstruktur yakni menggunakan pedoman wawancara dimaksudkan untuk memperoleh informasi sebanyak mungkin mengenai permasalahan yang diamati.

\section{HASIL PENELITIAN DAN PEMBAHASAN}

Hasil penelitian menunjukkan data Kepegawaian Bidang catatan Sipil di Dinas Kependudukan dan Catatan Sipil Kabupaten Gorontalo yang dilihat berdasarkan kondisi umum yaitu pada pada tingkat pendidikan SMA/SMK terdapat 6 orang $14,65 \%$, tingkat pendidikan D3 terdapat 3 orang $7,32 \%$, tingkat pendidikan S1 terdapat 29 orang $70 \%$, dan tingkat pendidikan terdapat 3 orang $7,32 \%$. Sehingga jumlah pegawai keseluruhan berjumlah 41 orang.

Dilihat dari sarana dan prasarana juga belum baik terutama untuk alat bantu pembuatan KTP. Kondisi tersebut belum sesuai dengan standar sarana dan prasarana yang ada tersebut seperti alat pembuatan KTP Camera terdapat 2 buah sedangkan di kantor tersebut hanya memiliki 1 buah camera, dan mesin cetak KTP terdapat 3 buah sedangkan di kantor tersebut hanya memiliki 2 buah mesin cetak karena 1 mesin cetak dalam keadaan rusak. Sarana dan prasarana yang bersifat administrasi maupun teknis operasional dapat dijalankan dengan efektif dan efisien apabila sarana dan prasarana yang ada di dalam organisasi sudah memadai.

Dan berdasarkan Sumber Daya Manusianya dapat dilihat bahwa petugas Operator Layanan yang ada di loket 1 sampai loket 8 hanya memiliki 4 orang staf pelayanan. Sementara 4 orang lainnya diambil dari bagian seksi pemerintahan. Untuk memaksimalkan pelayanan agar menjadi lebih baik diperlunya tenaga staf tambahan sejumlah 4 orang khusus yang ada di loket 1 sampai loket 8 agar petugas yang diambil dari seksi pemerintahan juga bisa kembali melaksanakan tugasnya sesuai dengan tugasnya masingmasing. Dan dibagian perekaman KTP hanya terdapat 2 orang sementara itu yang dibutuhkan lagi tenaga staf tambahan 1 orang.

\section{HASIL PENELITIAN}

Untuk mengukur dimensi Reliability dalam upaya mengetahui kualitas pelayanan publik di Disdukcapil Kabupaten Gorontalo dapat diukur melalui indikator sebagai berikut:

\section{Kecermatan Pegawai Dalam Melayani Pengguna Layanan \\ Berdasarkan hasil wawancara dengan Kepala Bagian Kepegawaian yang ada di Kantor Dinas}


Kependudukan dan Catatan Sipil Kabupaten Gorontalo yang menyatakan bahwa:

"Secara umum pelayanan di Kantor Dinas Kependudukan dan Catatan Sipil Kabupaten Gorontalo sesuai dengan prosedur yang berlaku. Kami mengedapankan asas pelayanan yang cermat, cepat dan tepat. Namun memang dalam beberapa kesempatan kami juga sadar bahwa masih terdapat masyarakat mengeluh terhadap proses pelayanan yang kami berikan. Hal ini tentu merupakan bagian yang harus dikoreksi secara terus menerus oleh kami".

Selanjutnya hasil wawancara dengan salah satu pegawai layanan menyatakan bahwa:

"Selama ini dalam melakukan proses pelayanan, pegawai selalu memberikan yang terbaik demi kepuasan masyarakat, sehingga jarang terjadi kesalahan yang dilakukan oleh pegawai layanan. Misalnya untuk mengurus mutasi penduduk, pegawai memberi tahu syaratsyarat yang harus dilengkapi oleh pengguna layanan. Ketika pengguna layanan sudah memenuhi syarat yang dibutuhkan, maka pegawai hanya mengecek ulang kelengkapannya lengkap atau tidak".

Berdasarkan wawancara dengan salah satu pegawai yang ada di Kantor Dinas Kependudukan dan Catatan Sipil Kabupaten Gorontalo yang menyatakan bahwa :

"Kami berusaha untuk cermat dalam melayani semua pengguna layanan yang datang kemari dengan berbagai keperluan. Kami mengecek kembali syarat-syarat yang dibutuhkan agar tidak terjadi kesalahan".

Dan berdasarkan wawancara dengan salah satu pegawai Administrasi Kependudukan yang ada di Kantor Dinas Kependudukan dan Catatan Sipil Kabupaten Gorontalo yang menyatakan bahwa:

"Terkadang petugas juga sering melakukan kesalahan. Kesalahan biasanya terjadi pada saat input data dari formulir ke KTP, baik salah ketik nama, tanggal dan tahun lahir. Yang paling mendasar kesalahan mengetik nama".

Dan berdasarkan hasil wawancara dengan salah satu mmasyarakat pengguna layanan di Kantor Dinas Kependudukan dan Catatan Sipil Kabupaten Gorontalo yang menyatakan bahwa:

"Kurang cermat, tapi ada beberapa karyawan saja yang cara 
pelayanannya bagus, pengalaman saya pernah mengurus e-KTP masih ada kesalahan dalam penulisan nama sehingga membuat saya harus bolak balik untuk membutuhkan pelayanan kembali. Kebanyakan rumah kita jauh dari kantor dan itu membuat pelayanan menjadi tidakefektiv."

\section{Memiliki Standar Pelayanan Yang Jelas}

Berdasarkan hasil wawancara dengan salah satu pegawai layanan ketika diwawancarai oleh peneliti yang menyatakan bahwa:

"Kami dalam menjalankan pelayanan pada masyarakat menggunakan SOP (Standart Operasional Procedure)". Karena bagi kami SOP itu merupakan pedoman bagi pegawai yang sebagai pelaksana pelayanan".

Kemampuan petugas / aparatur dalam menggunakan alat bantu dalam proses pelayanan

Berdasarkan hasil wawancara dengan Kepala Bagian Kepegawaian yang ada di Kantor Dinas Kependudukan dan Catatan Sipil Kabupaten Gorontalo yang menyatakan bahwa:

"Tidak semua pegawai layanan dapat mengoperasikan komputer, hanya pegawai yang mempunyai kemampuan khusus yang diberikan kewenangan untuk mengoperasikan alat bantu tersebut. Sehingga ketika pegawai yang berwenang tersebut tidak di tempat, pekerjaan yang menggunakan alat bantu menjadi sedikit lambat dan tertunda".

\section{Faktor Pendukung Kualitas Pelayanan Publik di Kantor Dinas Kependudukan dan Catatan Sipil Kabupaten Gorontalo}

Hasil penelitian tentang pelayanan di Disdukcapil Kabupaten Gorontalo yang ditemukan oleh peneliti melalui wawancara dan pengamatan langsung di lapangan menunjukkan bahwa terdapat beberapa hal yang menjadi faktor pendukung dari kualitas pelayanan publik di Disdukcapil Kabupaten Gorontalo, hal ini sebagaimana yang disampaikan oleh beberapa informan dimana faktor pendukung pegawai Disdukcapil Kabupaten Gorontalo berupa adanya dukungan dari Kepala Dinas sendiri dalam melaksanakan pelayanan tersebut. Ditambah lagi bentuk kerja sama pegawai Disdukcapil Kabupaten Gorontalo sehingga tugas dan kewajiban dilaksanakan dengan baik. Karena kerja sama merupakan faktor utama yang sangat penting yang biasa dilakukan oleh pegawai yang bekerja dalam satu organisasi yang terdiri dari berbagai macam orang dan kemudian membentuk satu tim untuk mencapai tujuan yang telah ditetapkan sebagai salah satu visi 
yang ingin dicapai pegawai Disdukcapil Kabupaten Gorontalo tersebut.

\section{PEMBAHASAN}

Kualitas pelayanan publik merupakan usaha untuk memenuhi segala sesuatu yang berhubungan dengan produksi, jasa, manusia, proses, lingkungan, dan yang menjadi kebutuhan serta keinginan konsumen baik itu berupa barang dan jasa yang diharapkan dapat memenuhi harapan dan kepuasan masyarakat sebagai pelanggan. Kualitas pelayanan secara umum harus memenuhi harapan-harapan pelanggan dan memuaskan kebutuhan mereka. Namun demikian meskipun definisi ini berorientasi pada pengguna layanan, tidak berarti bahwa dalam menentukan kualitas pelayanan penyedia jasa pelayanan harus menuruti semua keinginan konsumen. Kualitas pelayanan dapat diketahui dengan cara membandingkan persepsi pengguna layanan atas pelayanan yang mereka terima dengan pelayanan yang sesungguhnya mereka harapkan. (Tjiptono, 2005; 121).

Kualitas pelayanan dapat diketahui dengan cara membandingkan persepsi pengguna layanan atas pelayanan yang mereka terima dengan pelayanan yang sesungguhnya mereka harapkan, hal ini sejalan dengan apa yang dijelaskan oleh Sedarmayanti (1999) bahwa terdapat beberapa indikator untuk menentukan suatu kualitas pelayanan secara umum, bahwa pemberi layanan harus mampu menerjemahkan segala hal yang menjadi ketentuan main di dalam prosedur pelayanan yang dapat memberikan kepuasan kepada masyarakat.

Oleh karena itu untuk pihak Disdukcapil Kabupaten Gorontalo perlu meningkatkan kapasitas aparaturnya melalui bentuk kegiatan yang relevan dengan tugas dan fungsi yang diemban oleh aparaturnya. Masalah pada pelayanan publik pada dasarnya dapat dilihat dalam proses penyediaan pelayanan publik seperti kecermatan atau ketelitian pegawai dalam melayani pengguna layanan sangat penting bagi proses pelayanan. Jika pegawai tidak cermat dalam melayani masyarakat maka akan terjadi kesalahan dan menimbulkan pekerjaan baru. Seperti pada hasil temuan penelitian ketika pegawai salah ketik dalam penulisan nama pada KTP, maka pengguna layanan haru mengurus kembali nama yang salah tersebut. Dari ketidakcermatan tersebut akan menimbulkan pekerjaan baru yang seharusnya tidak perlu dilakukan oleh pegawai, serta akan menimbulkan penilaian yang kurang baik oleh pengguna layanan terhadap kualitas pelayanan yang diberikan.

Maka dari itu, Pertama pegawai harus cermat dalam mengerjakan tanggung jawab tugas 
khususnya yang berkaitan dengan pelayanan agar tercipta pelayanan yang baik dan masyarakat akan menilai baik. Jelas sekali bahwa pegawai dalam melakukan proses pelayanan harus cermat agar tidak terjadi kesalahan yang mengharuskan pengguna layanan mengurus kembali kesalahan yang dibuat oleh pegawai dikarenakan ketidakcermatan pegawai dalam melakukan proses pelayanan. Kedua memiliki Standar Pelayanan yang jelas. Di Disdukcapil Kabupaten sudah memiliki Standar Operasional Prosedur (SOP). Namun masyarakat pengguna layanan tidak semuanya mengetahui standar pelayanan di Disdukcapil Kabupaten Gorontalo.

Memiliki Standar Pelayanan yang jelas memang penting untuk pedoman pegawai dalam melayani pengguna layanan dalam proses pelayanan karena dengan berpatokan kepada standar pelayanan, proses pelayanan dapat berjalan dengan baik guna mencapai tujuan pelayanan khususnya di Disdukcapil Kabupaten Gorontalo. Ketiga Kemampuan dan keahlian dalam menggunakan alat bantu dalam proses pelayanan. Kehandalan dan kemampuan pegawai menjadi salah satu faktor penting dalam menentukan keberhasilan pelayanan yang diberikan oleh Kantor Dinas Kependudukan dan Catatan Sipil Kabupaten Gorontalo kepada masyarakat.
Tujuan dan sasaran harus dicapai oleh setiap pegawai pelayanan dengan cara melayani masyarakat sesuai prosedur pelayanan yang telah ditentukan serta dengan etika pelayanan yang benar. Secara umum kapasitas setiap personil yang ada dalam setiap instansi yang mengedepankan kepuasan dalam pelayanan yang diberikan harus mendapatkan porsi perhatian yang serius, serta tindakan yang nyata yang ditunjukkan dalam bentuk pelatihan atau upaya lain yang dapat meningkatkan kompetensi, serta prinsip kerja dan professional yang baik.

\section{Faktor Penghambat Pelaksanaan Tugas SDM}

Yang menjadi penghambat dalam proses pelayanan yang diberikan terdiri dari beberapa hal pokok, di antaranya adalah ketersediaan sumber daya manusia yang masih kurang, berupa tenaga staf dan lainnya, serta berbagai sarana dan prasarana layanan administrasi. Hal ini sebagaimana yang tercermin dalam hasil observasi dan temuan penelitian lainnya dalam bentuk wawancara dengan para informan. Hal hal tersebut dinilai sebagai kendala tekhnis dalam setiap aktivitas yang dilakukan dalam pelayanan. Pentingnya memproteksi kendala yang muncul sudah menjadi keharusan yang dilakukan oleh pihak yang ada di Kantor Dinas 


$\begin{array}{lcr}\text { Kependudukan } & \text { dan Catatan } & \text { Sipil } \\ \text { Kabupaten } & \text { Gorontalo } & \text { untuk } \\ \text { mengurangi } & \text { atau } & \text { bahkan } \\ \text { menghilangan } & \text { hambatan } & \text { yang } \\ \text { muncul di lapangan. } & \end{array}$

\section{SIMPULAN}

Berdasarkan hasil penelitian dan pembahasan, maka dapat ditarik kesimpulan yaitu:

Kualitas layanan yang diberikan pada Kantor Dinas Kependudukan dan Catatan Sipil Kabupaten Gorontalo secara umum masih kurang baik, hal ini dapat dilihat melalui beberapa hal terkait dengan Dimensi Reliability, Responsivenees, Assurance.

Faktor pendukungnya adalah motivasi kerja yang diberikan pegawai satu sama lain, dan bentuk kerja sama dari pegawai sendiri sehinnga dapat mewujudkan pelayanan yang baik.

Faktor penghambat kualitas layanan di Kantor Dinas Kependudukan dan Catatan Sipil Kabupaten Gorontalo dilihat dari beberapa hal, di antaranya adalah Kurangnya sumber daya manusia secara kuantitas maupun kualitas. Serta ketersediaan sarana dan prasarana tersebut menjadi penting untuk dilakukan oleh pihak yang berkepentingan dalam mencapai cita cita atau tujuan hadirnya pemerintahan di tengah masyarakat.

\section{SARAN}

Dapat dipahami bahwa suatu institusi publik yang berorientasi pada pelayanan harus memiliki semua hal yang menjadi pendukung kelancaran pelayanan publik tersebut, namun sebagaimana temuan peneliti yang diungkapkan sebelumnya, bahwa ketersediaan sarana dan prasarana masih menjadi kendala tersendiri dalam upaya memaksimalkan pelayanan kepada masyarakat. Pentingnya memproteksi kendala yang muncul sudah menjadi keharusan yang dilakukan oleh pihak yang ada di Kantor Dinas Kependudukan dan Catatan Sipil Kabupaten Gorontalo untuk mengurangi atau bahkan menghilangkan hambatan yang muncul di lapangan.

\section{DAFTAR PUSTAKA}

Hardiansyah. 2011. Kualitas Pelayanan Publik. Yogyakarta: Gava Media.

Kurniawan, Saefullah. 2005. Pengantar Manajemen. Jakarta: Murai Kencana.

Kurniawan. 2005. Transformasi Pelayanan Publik. Yogyakarta: Pembaharuan.

Moleong. 2009. Metode Penelitian Kualitatif. Bandung: PT Remaja Rosdakarya.

Sedarmayanti. 1999. Manajemen

Sumber Daya Manusia (Manajemen Kepegawaian). Bandung: Mandar Maju. 
Sedarmayanti. 2010. Sumber Daya

Manusia dan Produktivitas

Kerja. Bandung: CV Bandar

Maju

Sugiyono. 2009. Memahami

Penelitian Kualitatif. Bandung:

Alfabeta.

Sugiyono. 2007. Metode Penelitian

Kualitatif Kuantitatif.

Bandung, Alfabeta.

Tjiptono F. 2007. Service, Quality, \&

Satisfacation. Yogyakarta:

Andi Offset.

Tjiptono F. 2011. Service

Management Mewujudkan

Layanan Prima. Edisi 2.

Yogyakarta: Andi Offset. 